\title{
Institutional barriers to organic farming in Central and Eastern European countries of the Baltic Sea region
}

\author{
Markus Larsson ${ }^{1,2^{*}+}$, Louise Morin ${ }^{1 \dagger}$, Thomas Hahn ${ }^{1}$ and Johanna Sandahl ${ }^{3}$
}

* Correspondence:
markus.larsson@mdh.se
${ }^{\dagger}$ Equal contributors
${ }^{1}$ Stockholm Resilience Centre,
Stockholm University, Kräftriket 2B,
Stockholm SE-106 91, Sweden
${ }^{2}$ Mälardalens högskola, Box 883,
Västerås 721 23, Sweden
Full list of author information is
available at the end of the article

* Correspondence: markus.larsson@mah.se ${ }^{1}$ Stockholm Resilience Centre, Stockholm University, Kräftriket 2B Stockholm SE-106 91, Sweden ola, Box 883 Full list of author information is avallable at the end of the article

\begin{abstract}
A window of opportunity to promote organic farming is open for the Central and Eastern European Countries (CEEC) that joined the EU in 2004. The development of organic farming has the potential to decrease the amount of nutrient leaching to the Baltic Sea and could help to stop the environmental degradation of the Sea. However, this requires a diverse set of institutions. This paper explores the institutions that are lacking to promote the full development of organic farming in the CEEC, using Sweden as a baseline reference. A case study approach, formalised by introducing a set of indicators, has been used to identify the missing institutions. Data have been obtained from a desktop study, including a literature review, interviews and a questionnaire. The case studies partially support previous studies proposing that the development of organic farming proceeds along six steps: establishment of an organic farming community; establishment of political recognition; establishment of financial support; establishment of non-competitive relationships between the organic sector and general agricultural institutions; establishment of an organic food market; and development of a discussion and coordination arena. The results show that market development is the least developed step and that there is a correlation between higher governmental engagement and a more developed organic sector.
\end{abstract}

Keywords: Organic farming, Institutions, Baltic sea, Poland, Baltic states

\section{Introduction}

\section{Background}

In 1987, all the countries around the Baltic Sea agreed that by 1995, there should be a reduction of $50 \%$ of the nutrient load reaching the Sea. This goal is still unachieved and the environmental degradation of the Baltic Sea continues (HELCOM 2011). From all the input sources, agriculture is the biggest one and accounts for almost $50 \%$ of all the nutrients leaching to the sea. Almost half of those agricultural run-offs come from Poland, Estonia, Latvia and Lithuania and their share is likely to increase. The dissolution of the Soviet block in 1989 and the consequent entry into market economy had a significant effect on the economies of the Central and Eastern European countries (CEEC). The subsequent crash in farm-gate prices of most agricultural products and the reorganisation of the agricultural sector resulted in a more extensive land use where the utilisation of pesticides and chemical fertilizers was dramatically reduced

(c) 2013 Larsson et al.; licensee Springer. This is an Open Access article distributed under the terms of the Creative Commons Attribution License (http://creativecommons.org/licenses/by/2.0), which permits unrestricted use, distribution, and reproduction in any medium, provided the original work is properly cited. 
(Petersen and Hoogeveen 2004). However, as their economies recover, their agricultural practices are predicted to intensify again, a fact that is noticeable in the Baltic States (HELCOM 2011).

According to a review by Stolze et al. (2000), organic farming achieves higher biodiversity than conventional agriculture, due to the bans on pesticide, higher habitat heterogeneity and more extensive land use overall. Furthermore, organic farming generally decreases soil erosion, and conserves soil fertility and soil system stability to a higher degree than conventional farming. These properties can decrease the amount of nutrients leaching from agricultural land that result in eutrophication (Stolze et al. 2000; Larsson and Granstedt 2010). In turn, this has indirect, yet significant, effects on fisheries and tourism sectors (HELCOM 2004; Diaz and Rosenberg 2008). HELCOM ${ }^{\mathrm{a}}$ stresses that in the future "the EU agricultural policy will play a major role in the development of the condition of the Baltic Sea" (HELCOM 2011, p. 86). Researchers point out that the environmental degradation of the Baltic Sea cannot be resolved without addressing the agricultural run-offs, and that these can be managed efficiently by organic farming (HELCOM 2002; Granstedt et al. 2005). Thus, organic farming provides an array of public goods to society.

A study by HELCOM (2002) reveals that in order to attain the $50 \%$ reduction goal of nutrients, there would be a need for all agricultural land in the Baltic Sea drainage basin to turn organic or for half of the land to be set aside. The first solution implies a $25 \%$ reduction in yield, the second a $50 \%$ reduction. From this point of view, mass conversion to organic farming seems more attractive than to maintain conventional farming on a smaller area. In turn, this implies a high potential for the development of organic farming in all the CEEC, a fact that is recognised in the rural development plans of all countries under study. The accession of some CEEC to the European Union makes the realisation of this potential even more plausible. By opening a market, and by contributing new knowledge and providing new subsidies devoted to organic agriculture through the Common Agriculture Policy (CAP), the EU enlargement has opened a window of opportunity in the CEEC to promote the growth of the organic sector (Fischler 2003). The outcome of the currently on-going (Feb 2013) negotiations of reform of the CAP will determine whether additional resources will be targeted towards organic agriculture.

\section{Objectives, research questions and limitations}

The overall aim of this paper is to understand which institutional factors may hinder the growth of the organic sector in CEEC $C^{b}$. The study mostly focuses on formal institutions and the role of governments in developing them. In doing so, we describe and compare the institutions and actors of the organic sector in four CEEC (Estonia, Latvia, Lithuania, and Poland) and one Western European country (Sweden) by using a comprehensive set of indicators. Sweden is used as a baseline country which has a complete organic sector with all necessary institutions (Michelsen \& Søgaard 2001; Dabbert et al. 2004). Sweden was chosen because it has production conditions (e.g. climate) similar to the Baltic States if not to Poland and because it lies within the drainage basin of the Baltic Sea to a larger extent compared to Denmark or Germany. The studied CEEC also lie completely within the drainage basin of the Baltic Sea, making them good candidates in reducing the eutrophication rate. Poland and the three Baltic States were also 
selected because of their high potential for organic farming and the window of opportunity that is open for them.

The following research questions were identified as central to the objective: What organic farming institutions already exist in Sweden and the four CEEC? How do these correspond or differ between each country? What institutions need to be developed to support the organic sector in the CEEC?

\section{Case study description}

Estonia, Latvia, Lithuania, Poland and Sweden are all members of the EU (since 2004 for the CEEC and since 1995 for Sweden). The CEEC cover 28.5\% of the Baltic Sea Drainage Basin (BSDB) area (see Figure 1), while being inhabited by $55 \%$ of the population. In contrast, Sweden covers $25 \%$ but is only inhabited by $10 \%$ of the population of the BSDB (Hannerz and Destouni 2006). Furthermore, 58\% of the agricultural land of the BSDB is in the CEEC, while 7\% is within Sweden. The Baltic States are similar to Sweden in terms of population and agricultural land, but Poland is more populated and has more agricultural land.

CEEC have a 33-42\% lower GDP per capita than the average of the EU27, and half the income per capita of Sweden (Eurostat 2012a). The agricultural sector has a larger share of the economy and more people live in rural areas and work in the agricultural sector in CEEC than in the EU27. During the communist regime, Polish land ownership was kept mostly private, while the farms in the Baltic States were mostly converted to collectivised farms (Lerman 2001). Post-independence land privatisation resulted in small individual farms in Poland and Latvia while Estonia and Lithuania have kept about $20 \%$ of large private corporate farms (FAO 2002). Organic farming started in the 1930's in Sweden, although the first organic standard was crafted in 1985 (Källander 2000/2010). In CEEC, organic farming started after they regained independence when the Soviet Union collapsed (Prazan et al. 2004).

\section{Methods and theoretical framework}

\section{Case study approach}

A comparative case study approach has been used. This includes multiple sources of evidence - a mail-out questionnaire (described below), personal communications and a review of research and official reports, regulation texts and grey literature (Yin 2003). The analysis was standardised through the use of indicators. The case studies were compared to a framework provided by Michelsen et al. (2001).

\section{Questionnaire and personal communications}

The data gathered during the desktop study were complemented by e-mail or telephone interviews with experts working in the organic sector. The point of making these contacts was to confirm and fill any gaps in the collected data. Data were also gathered using a questionnaire distributed to a limited number of research institutions, farmers' associations, certification bodies and governmental agencies. The questionnaire covered six different topics - legislative support, financial support, market, production, social dynamics and infrastructure availability - that required detailed knowledge to be answered correctly. The topics were selected following the literature review. One 


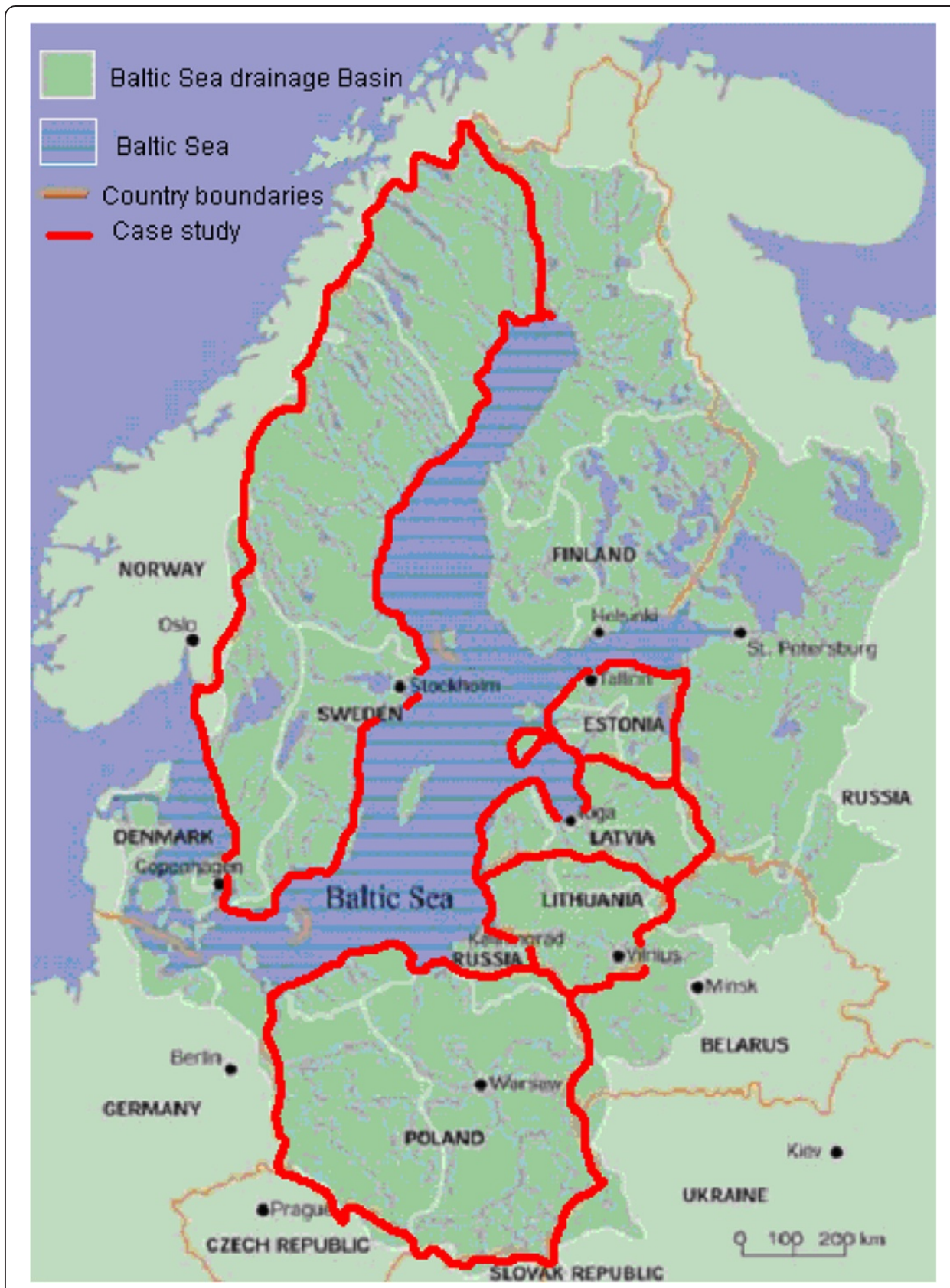

Figure 1 The Baltic Sea drainage basin and the studied countries.

constraint encountered with personal communication was that some respondents did not have good enough knowledge of English to answer all the questions. The first respondents that were contacted were singled out from the literature review or from lists of participants in organic agriculture seminars and workshops. A subsequent 'snowball' effect led to further people being identified (Schultz et al. 2007; Sandström 2008). Since some respondents had a vested interest in the promotion of organic farming, a possible bias in their responses should be noted. In all, ten senior officials or researchers from Poland, the three Baltic countries and regional organisations answered the questionnaire. Even though the number of respondents was limited, the questionnaire provides 
valuable information about the conditions for organic farming in the region due to the central positions of the respondents.

\section{Conceptual and theoretical framework - Institutions of the organic sector}

Ultimately, the development of organic farming depends on the willingness of individual conventional farmers to convert to organic farming practices. In turn, this willingness depends to a large extent on the institutional system in which the farm is embedded (Michelsen et al. 2001). Some systems contain adequate institutions to promote the development of organic farming, others do not. Michelsen et al. (2001) and Prazan et al. (2004) have identified institutions from three societal domains - civil society, market and state - as key components for the development of the organic sector. In this paper, civil society includes institutions and organisations that are not government-controlled (Baylis and Smith 2001), e.g., producers' associations, informal farming practice guidelines, and non-state organisations that participate in lobbying, research and education. The market domain includes marketing initiatives, consumers, and food chain actors, such as processors and retailers. The state includes agricultural regulations, standards for organic certification and labelling and different kinds of support. Here, institutions are defined as the norms and rules that steer the behaviour of individuals. Norms and rules can be formalised by being carried out by an organisation, either from civil society or by the state. They can also be informal, that is perpetuated by culture and routine (North 1990). Prazan et al. (2004) also emphasise that the immaturity of the organic sector means that it lacks many formal institutions available to conventional agriculture: a detailed regulatory framework; a wide range of policy measures; a complete research program; adequate and widespread training and advisory services; and a complete market.

\section{Six steps of institutional development}

Michelsen et al. (2001) suggest that the institutional development of organic farming proceeds along six steps. The first three are seen as essential for the initial growth of the sector, while the last three are seen as essential for the continuous growth. The steps can be undergone multiple times, a process that leads to further development. All the steps do not need to have been completed before a step is repeated (Michelsen et al. 2001; Moschitz et al. 2004). Each step includes formal and informal institutions. Following a literature review, thirty four indicators were developed to assess the degree of completion of the six steps suggested by Michelsen et al. (2001) as well as the characteristics of the civil society, state and market domains, see Table 1 below. Throughout the text, indicator numbers are given in parentheses. These indicators refer to the property of the institution or actor that is being described and have been used to assess the degree of completion of the steps in the result analysis.

Step 1: The establishment of an organic community starts by the self-organisation of a group of organic farmers into a producers' association. Michelsen et al. (2001) identify the acceptance of a formalised common standard that specify the requirements to be considered organic as the first step in developing the organic community identity (indicator 1). Moschitz et al. (2004) argue that maintaining the validity of private standards helps the organic community to keep a strong identity after the involvement of the 
Table 1 The six steps of institutional development and indicators with which they can be assessed Characteristics of the completed step
Step 1: Establishment of an organic community Indicators used to assess the characteristic

a) The organic community has a strong identity b) Producers' associations have the power to influence other parts of society

\section{Step 2: Establishment of political recognition}

a) Regulatory support exists

b) Financial support is high

c) Strategic support is high

\section{Step 3: Establishment of financial support}

a) Financial support has been introduced

b) Area payments are high enough to off-set the cost incurred by conversion and lower productivity

c) Research program is well-funded and complete

d) There are financial schemes to help organic farmers
1: Introduction of first standard (date)

2: Number of national producers' associations

4: Private standard can still be used

3: Power of producers' association

5: Proportion of organic farmers that are members of an association (\%)

6: Introduction of first national regulation (date)

7: Introduction of current regulation (date)

10: Introduction of area payment (date)

11: Area payment (euro/ha)

12: \% of agri-environmental scheme devoted to organic farming

13: Total amount devoted to OF (millions of euro)

15: Loans available for improvement of organic farms

16: Lower taxes for organic farmers

17: Certification/inspection costs reimbursement

18: Research support (million euros/year)

20: Action plan for organic farming

21: OF incorporation in strategic plan of government

22: Quantitative target for proportion cultivated organically (\%)

10: Introduction of area payment (date)

11: Area payment (euro/ha)

13: Total amount devoted to organic farming (millions of euro/year)

14: \% uptake of area support

18: Research support (million euro/year)

19: Estimate \% of agricultural research funding to organic farming

25: Range of research program

15: Loans available for improvement of organic farms

16: Lower taxes for organic farmers

17: Certification/inspection costs reimbursement

18: Research support (million euro/year)

\section{Step 4: Development of non-competitive relationships}
a) Partnership
b) Integration of organic farming in state institutions

8: Partnerships strength

23: Specific office in agricultural ministry

24: Degree of integration of OF in training establishments

26: Degree of integration of OF in advisory services

c) Discussion arena existence
9: Discussion arena existence 
Table 1 The six steps of institutional development and indicators with which they can be assessed (Continued)

\begin{tabular}{ll}
\hline d) Strength of the organic community identity & 1: Introduction of first standard (date) \\
& 2: Number of national producers' associations \\
& 4: Private standard can still be used \\
& 3: Power of producers' association \\
e) The power a producers' associations has & 5: Proportion of organic farmers that are members of an \\
& association (\%)
\end{tabular}

Step 5: Establishment of organic food market
a) A complete supply chain exist
27: Number of certified processing facilities (2004)
28: Promotion by large retailers
29: Distribution of sales channels
b) Other structural conditions are favourable
34: Perception of the quality of certification and control system
c) The behaviour of the general consumers is favourable
31: Proportion of consumer that can correctly define organic farming (\%)
32: Acceptable price premium by $50 \%$ of the population
33: \% of the population that buy OP > once a week/>once a month/< once a month
d) The market share of organic farming is large
30: Market share of organic products (\%)

Step 6: Development of a committed institutional setting
a) An inclusive discussion arena exists
9: Discussion arena existence
b) An inclusive coordination arena exist
20: Action plan for organic farming

Note that some indicators are relevant for more than one step.

state in certification and standard setting (indicator 4). The power of the producers' association increases with its level of inclusiveness (indicator 5) (Boström 2006).

Step 2: The introduction of private standards is strengthened by political recognition. This gives credibility and ensures that a minimum set of requirements is uniformly applied nationally (Michelsen et al. 2001; Dabbert et al. 2004). At this stage, organic farming is recognised under law as an alternative way of practicing agriculture (indicators 6-7). However, political recognition is usually further anchored by implementing other types of support, such as financial (indicators 10-19) and strategic support (indicators 20-22) (DFAF 2001; Moschitz et al. 2004).

Step 3: Financial support usually takes the form of area payments that can be differentiated by crops and regions, depending on the policy objectives (Michelsen et al. 2001). These subsidies are paid for each hectare that is cultivated organically (indicators 11 and 13). The introduction of area payment triggers the initial growth of the organic sector (indicator 10). Area payments for organic farming are co-financed by the EU via the funding of CAP and the higher the payment support, the more profitable organic farming becomes, and the larger the rate of growth (Dabbert et al. 2004). Other forms of financial support, such as reimbursement of certification fees or guaranteed loans, are particularly relevant in the CEEC where most farmers survive on very low profit margins (indicators 15-17) (Prazan et al. 2004). Furthermore, financial support should involve research and development because this is what trigger innovations in any market domain and makes it competitive (indicators 18 and 25) (EU 2004). 
Step 4: Establishment of non-competitive relationships between the organic sector and general agricultural institutions (from both the civic and state domains). This interaction can take three forms: cooperation, competition and creative conflict (Michelsen et al. 2001). Under purely cooperative relationships, the differences between each sector are not stressed and there is a risk that the organic sector loses its identity by being incorporated into the conventional sector (indicators 1, 4, 23, 24 and 26). Under purely competitive relationships, the organic sector is hindered by a lack of contact between the organic and the conventional sector. Political, financial and strategic support (e.g. action plan) is missing. The middle point on this continuum is what Michelsen et al. (2001) call "creative conflict", where discussion takes place between each sector without one being subordinate to the other. The organic sector in this case must have a strong identity and potential to influence society (indicators $1-5$ ).

Step 5: To maintain the growth of the organic sector there is a need for a mature and independent organic food market (Michelsen et al. 2001). This necessitates the establishment of a complete supply chain, which includes producers, processors, distributors and retailers (indicators 27-29). A complete supply chain will favour supermarkets as sale channel and will increase the availability of organic products (indicator 29), which in turn will increase demand (indicator 33) and supply (indicator 30) (Terra Nord 2005). Another important characteristic of the organic market is the price premium of organic products (indicators 32). Consumers that are more knowledgeable about organic farming will be willing to pay a higher price premium (indicator 31) (DFAF 2001). The demand for organic products increases when certification authority is considered reliable (indicator 34) (DFAF 2001).

Step 6: Establishment of an institutional setting including a discussion arena, which eases the coordination among all the actors. This could be the administrative committee and council of the certification organisation (Boström 2006) or an advisory council in the ministry of agriculture (Zerger et al. 2005) (indicator 9). Coordination is eased by the creation and implementation of national action plans (indicator 20) (DFAF 2001).

\section{Definition of organic farming}

In this paper, organic farming is defined according to the EU regulation (EC) 834/2007 that specifies the basic requirements needed in terms of production, certification, labelling and processing that must be implemented in each member state. The regulation defines organic farming as a way of producing agricultural goods that restrict the use of off-farm inputs in favour of other farming practices (cultural, biological and mechanical) that can be established on any farm after a period of conversion.

\section{Results}

\section{Factors influencing organic farming in CEEC}

The results from the questionnaire are summarised in Table 2. Market development and financial support are deemed more important than the social dynamic of the rural region (e.g., ageing population or out-migration), and infrastructure problems (e.g., rural services, state of road network), which did not qualify among the top 15 most 
Table 2 Factors with the largest influence on the development of organic farming (OF) in CEEC

\begin{tabular}{|c|c|c|c|c|}
\hline Rank & Type & Factors & Scale & \\
\hline 1 & $\mathrm{~F}$ & Public investment in processing of organic products & Domestic & ++ \\
\hline 2 & M & Consumer demand for organic products & Domestic & ++ \\
\hline 3 & $\mathrm{~F} / \mathrm{M}$ & Public investment for marketing of organic products & Domestic & ++ \\
\hline 4 & S & Integration of OF in national rural development plan & Domestic & + \\
\hline 5 & $\mathrm{~F}$ & Area payment for conversion to OF & Domestic & + \\
\hline 6 & $\mathrm{~F}$ & Public expenditure in extension services and training & Domestic & ++ \\
\hline 7 & $\mathrm{~F}$ & Public investment in research and development in OF & Domestic & ++ \\
\hline 8 & M & $\begin{array}{l}\text { Consumer concerns about food quality, food safety, environmental protection } \\
\text { and animal welfare }\end{array}$ & Domestic & ++ \\
\hline 9 & $\mathrm{~F}$ & Area payment for maintenance of OF & Domestic & + \\
\hline 10 & M & Link between producers and retailers & Domestic & + \\
\hline 11 & M & Consumer demand for organic products & EU & + \\
\hline 12 & $P$ & Availability of organic producers' association & Domestic & ++ \\
\hline 13 & $P$ & Political power of organic producers' association & Domestic & + \\
\hline 14 & M & $\begin{array}{l}\text { Consumer concerns about food quality, food safety, environmental protection } \\
\text { and animal welfare }\end{array}$ & EU & + \\
\hline 15 & $\mathrm{~F}$ & Other financial help (e.g. guarantee loan, compensation for lost crop, etc.) & Domestic & + \\
\hline
\end{tabular}

important factors. Production factors that concern the producers' associations and integration of organic farming within strategic documents are also considered important. 13 out of 15 factors concern domestic obstacles.

\section{Characteristics of the civil society domain}

Producers' associations first appeared in the 1990's in CEEC and in the 1980's in Sweden (indicator 1, Table 3). The questionnaire reveals that although they appeared long ago, their power needs to increase significantly $(++)$ in order to promote the organic sector development (Table 2; indicator 3 Table 3). In Latvia, Sweden and Lithuania there is one main producers' association for organic farmers, making them largely representative (indicator 2 and 5). In Poland, there are numerous small and local producers' associations (indicator 2), and no official record keeping of the membership is done, preventing the measurement of indicator 5. In Estonia, there are two national producers' associations and many smaller, local ones (indicator 2). Membership has been decreasing (Moschitz et al. 2004) and an estimate suggests that as few as 10-15\% of organic farmers are part of any organic association, making the Estonian producers' associations hardly representative (indicator 5).

\section{Characteristics of the state domain}

In CEEC, new regulations were adopted in 2000 or 2001 in anticipation of their accession to the EU. Today, organic farming in all the studied countries is regulated based on regulation (EC) No $834 / 2007^{\mathrm{C}}$ of the EU (indicator 7). In Sweden and Lithuania, partnerships are frequent and thorough, while in Estonia and Latvia they are infrequent 
Table 3 Indicator 1-5 describing the institutions of the civil society domain

\begin{tabular}{|c|c|c|c|c|c|c|}
\hline & & Estonia & Latvia & Lithuania & Poland & Sweden \\
\hline 1 & Introduction of 1st private standard & 1989 & 1994 & 1992 & 1994 & 1985 \\
\hline 2 & $\begin{array}{l}\text { Number of national producers' } \\
\text { associations }\end{array}$ & 2 & 1 & 1 & 7 & 3 \\
\hline 3 & Power of producers' associations & $\begin{array}{l}\text { Need to be } \\
\text { increased }\end{array}$ & $\begin{array}{l}\text { Need to be } \\
\text { increased }\end{array}$ & $\begin{array}{l}\text { Need to be } \\
\text { increased }\end{array}$ & $\begin{array}{l}\text { Need to be } \\
\text { increased }\end{array}$ & Good \\
\hline 4 & Private standard can still be used & No & No & Yes & Yes & Yes \\
\hline 5 & $\begin{array}{l}\text { Proportion of organic farmers } \\
\text { in producers' associations }\end{array}$ & $10-15 \%$ & $\approx 60 \%$ & Most & nd & $90-100 \%$ \\
\hline
\end{tabular}

1) EE: Milkk 2005, LV: Zarina 2009, LT: Kaspersen et al. 2004, PL: Metera 2005, personal communication, Josef Tyburski, Mazury University, Olsztyn, Poland, SE: Källander 2000/2010.

2) EE: Vetemaa \& Milkk 2012, LV: Zarina 2009, Drozdovska 2005, LT: Kaspersen et al. 2004, PL: Kilcher et al. 2011, SE: Schusseleder 2009.

3) CEEC: based on questionnaire, SE: Kilcher et al. 2011.

4) CEEC: Tyburski \& Zakowska-Biemans 2003, SE: Boström \& Klintman 2003.

5) EE: personal communication Eve Ader, Estonian Plant Production Inspectorate, LV: Drozdovska Drozdovska 2005, LT: Kaspersen et al. 2004, PL: personal communication, Josef Tyburski, Mazury University, Olsztyn, Poland, SE: estimate by comparing number of organic farms in Figure 2 and the number of organic farms member of different associations, Schusseleder 2009.

and irregular. In Poland, they are increasingly frequent (indicators 8-9). The main discussion arena of Sweden is the administrative board and committees of KRAV, a certification body which includes members of most interest groups (e.g., food industry, environmental and animal protection organisations, and producers' associations) involved in the development of the organic sector (Boström 2006). In Poland, the discussion arena is a council, hosted by the Ministry of Agriculture and Rural Development. In Latvia, actors within the government sometimes participate in the board meeting of the organic producers' association. However, no formal discussion arena has been established that would group all the actors (Table 4).

Financial support appeared early in Lithuania and Sweden, long before their accession to the $\mathrm{EU}$ and before funds were made available for member states through regulation (EEC) $2078-92^{\mathrm{d}}$ (indicator 10). The other countries implemented payment schemes later, through the pre-accession structural funds, such as SAPARD and PHARE. Area payments for organic farming vary between 40 and 855 euro per hectare (indicator 11) and represent between $8 \%$ and $80 \%$ of the money invested in protecting the

Table 4 Indicator 6-9: institutions of the state domain related to general political recognition

\begin{tabular}{llccccc}
\hline & & Estonia & Latvia & Lithuania & Poland & Sweden \\
\hline 6 & First national regulation & 1997 & 1996 & 1994 & 2001 & $1995^{*}$ \\
7 & Current regulation & 2009 & 2009 & 2009 & 2009 & 2009 \\
8 & Strength of partnership & Weak & Weak & Good & Medium, increasing & Good \\
9 & Discussion arena existence & No longer & No & Nd & Yes & Yes
\end{tabular}

6) CEEC: Tyburski \& Zakowska-Biemans 2003, EE: Vetemaa \& Milkk 2012, LV: Zarina 2009, LT: Kaspersen et al. 2004, PL: Metera 2005, SE: Lampkin et al. 1999. ${ }^{*}$ In Sweden, the regulation for organic farming is not detailed and is limited to the requirement of EU regulations, Kilcher et al. 2011.

7 All: The basic rules of organic farming are uniform in all European Union member states. From January 1 st, 2009 the new EU Organic Farming Regulations (EC) No 834/2007 and (EC) No 889/2008 came into effect (Vetemaa \& Milkk 2012). 8) EE: personal communication Eve Ader, Estonian Plant Production Inspectorate; Moschitz et al. 2004, LT: personal communication, Leviana Sturite, State Stende Cereals Breeding Institute, Latvia, PL: personal communication, Josef Tyburski, Mazury University, Olsztyn, Poland; Moschitz et al. 2004, SE: Kilcher et al. 2011.

9) EE: personal communication Eve Ader, Estonian Plant Production Inspectorate, LV: personal communication, Leviana Sturite, State Stende Cereals Breeding Institute, Latvia; unpublished observation, Latvian Organic Agriculture Association, PL: personal communication, Josef Tyburski, Mazury University, Olsztyn, Poland; Moschitz et al. 2004, SE: Källander 2000/2010. 
environment in agricultural land (indicator 12). The uptake rates for area payments vary between $50 \%$ and $240 \%$ (indicator 14 ). The $240 \%$ uptake rate of Sweden is due to the possibility of obtaining area payment without being certified.

Area payments are not the only types of possible financial support (indicators 15 to 19). In Lithuania and Poland, there is a larger diversity of financial measures than in Estonia and Latvia. Lack of financial support was the number one factor hindering the development of the organic sector in CEEC in the 1990's (Zobena 1998), and although it has increased a lot since the accession to the EU, it is still listed as a serious hindering factor in the questionnaire and other case studies (see for example Buciene and Eidukeviciene 2005; Hajduk and Staniszewska 2005). The questionnaire identified the lack of public investment in processing, marketing, area payments, advisory services and research as being among the top 10 factors hindering the development of the organic sector, see Table 2. In CEEC, it seems that there is a lack of information for farmers about agri-environmental schemes (including organic area payments) and that measures for intensive agriculture have priority over agri-environment schemes (IUCN 2004) (Table 5).

The rural development plan of each country includes provisions for organic farming (indicator 21). However, the questionnaire reveals that in CEEC integration of organic farming in rural development is the fourth most important factor hindering organic farming and needs to be increased (see Table 2). All the countries except Poland have an action plan for coordinating organic farming development (indicator 20). In Sweden and Lithuania the quantitative target set up in these action plans is relatively high: at

Table 5 Indicator 10-19: Institutions of the state domain related to financial support

\begin{tabular}{|c|c|c|c|c|c|c|}
\hline & & Estonia & Latvia & Lithuania & Poland & Sweden \\
\hline 10 & Introduction of area payment & 2000 & 2001 & 1993 & 1999 & 1989 \\
\hline 11 & Area payment (Euro/ha) & 80 & 82-139 & $118-734$ & $55-382$ & $40-855$ \\
\hline 12 & $\begin{array}{l}\% \text { of agri-environmental scheme devoted to } \\
\text { organic farming }\end{array}$ & 16 & 80 & 72 & 8 & 25 \\
\hline 13 & $\begin{array}{l}\text { Total amount devoted to organic farming } \\
\text { (millions of euros/year) }\end{array}$ & 3.1 & 4.9 & 15 & 7 & 57.8 \\
\hline 14 & $\%$ uptake of area support & $80 \%$ & $93 \%$ & $50-60 \%$ & $88 \%$ & $240 \% *$ \\
\hline 15 & Loans available for improvement of organic farms & No & No & Yes & Yes & nd \\
\hline 16 & Lower taxes for organic farmers & No & No & Yes & Yes & nd \\
\hline 17 & Certification/inspection costs reimbursement & No & No & Yes & Yes & No \\
\hline 18 & Research support (million euros/year) & 0.1 & 0.1 & 0.046 & 0.27 & $5.9^{* *}$ \\
\hline 19 & $\begin{array}{l}\text { Estimate } \% \text { of agricultural research funding } \\
\text { devoted to organic farming }\end{array}$ & $1 \%$ & $19 \%$ & $6.3 \%$ & $0.2 \% * * *$ & $10 \%$ \\
\hline
\end{tabular}

10) EE: Vetemaa \& Milkk 2012, LV: Zarina 2009, LT: Kaspersen et al. 2004, PL: Metera 2005, SE: Källander 2000/2010.

11) EE: Prazan et al. 2004, LV: Latvian Ministry of Agriculture 2006a, LT: Rush 2006, Lithuanian Ministry of Agriculture 2006, PL: Porter 2006, Polish Ministry of Agriculture and Rural Development 2006b, SE: Swedish Board of Agriculture 2012.

12) EE, LV, LT, SE: Tuson \& Lampkin 2006, Hrabalova et al. 2005, PL: Polish Ministry of Agriculture and Rural Development 2006b.

13) EE, SE: Tuson \& Lampkin 2006, Hrabalova et al. 2005, LV: Drozdovska 2005, PL: Polish Ministry of Agriculture and Rural Development 2006a, LT: Lithuanian Ministry of Agriculture 2005.

14) EE, LV, PL, SE: Tuson \& Lampkin 2006, Hrabalova et al. 2005, LT: Lithuanian Ministry of Agriculture 2006. * In Sweden, a farm does not need to be certified to get payment for organic farming.

15) All: Tuson \& Lampkin 2006, Hrabalova et al. 2005.

16) All: Prazan et al. 2004.

17) All: Tuson \& Lampkin 2006, Hrabalova et al. 2005.

18) All: Slabe $2004 .{ }^{* *}$ The total research funding includes forestry and fisheries. Thus, the number is likely to be smaller than this.

19) EE: Statistics Estonia 2007, LV: Latvian council of science 2006, LT: Slabe 2004, PL: Polish Central Statistical office 2007, SE: Slabe 2004. ${ }^{* *}$ Approximation based on two different years. 
Table 6 Indicator 20-22: Institutions of the state domain related to strategic support

\begin{tabular}{llccccc}
\hline & & Estonia & Latvia & Lithuania & Poland & Sweden \\
\hline 20 & Action plan for organic farming & Yes & Yes & Yes & No & Yes \\
21 & OF incorporation in strategic plan of government & Yes & Yes & Yes & Yes & Yes \\
22 & $\begin{array}{l}\text { Quantitative target for the proportion of agricultural } \\
\text { land that should be organic }\end{array}$ & Yes & No & Yes & No & Yes \\
& & & & & \\
\hline
\end{tabular}

20) All: Slabe Slabe 2004, EE: Estonia ministry of agriculture 2002, LV: Zarina 2009, Prazan et al. 2004, LT: Jansen \& Simon 2005, Rush 2006, Prazan et al. 2004, PL: Prazan et al. 2004, SE: Kilcher et al. 2011.

21) Estonian Ministry of Agriculture 2006, Latvian Ministry of Agriculture (2006b), Lithuanian Ministry of Agriculture (2006), Polish Ministry of Agriculture and Rural Development (2006b), Swedish Ministry of Agriculture 2008

22) EE: Kalm \& Laansalu 2002, LV: personal communication, Leviana Sturite, State Stende Cereals Breeding Institute, Latvia, LT: Jansen \& Simon 2005, Rush 2006, PL: Prazan et al. 2004, SE: Statistics Sweden 2012.

least $15-20 \%$ of the agricultural land should be cultivated organically by some given year (indicator 22) (Table 6).

The integration of organic farming within the state domain varies greatly (Table 7). It is most integrated in Latvia, Poland and Sweden, least integrated in Estonia and Lithuania. Research is almost exclusively carried out by institutes subsidised by the state. The implementation of a full research programme occurs only in Sweden and Lithuania, although Poland has a full programme for crop research (indicator 25). In Estonia, integration of organic farming is weak. In all other countries, advising services are provided by the same advisory and training centre as conventional agriculture. In Poland and Sweden, the main agricultural universities offer organic farming courses in their curricula.

\section{Characteristics of the market domain}

Indicators 27 to 29 show that all the actors of the supply chain are present in Sweden, while both processors and distributors are very limited in CEEC. The lack of processing facilities is one of the most important factors that hinder the development of the organic sector in CEEC according to the questionnaire and to previous studies (Milkk Milkk 2005; Terra Nord 2005; Buciene and Eidukeviciene 2005; Hajduk and Staniszewska 2005). Indicator 29 shows that supermarkets account for more than 75\% of all the sales in Sweden. Favoured sales channels in CEEC are typically direct sales and market places. The market share of organic products is low but still substantially higher in Sweden (4.1\%) than in other countries (indicator 30). However, this somehow contradicts the results from the literature review which suggests that people in

Table 7 Indicator 23-26: Integration of the organic sector within agricultural institutions of the state domain

\begin{tabular}{llccccc}
\hline & Estonia & Latvia & Lithuania & Poland & Sweden \\
\hline 23 & $\begin{array}{l}\text { Specific office in } \\
\text { agricultural ministry }\end{array}$ & Yes & No & Yes & Yes & No \\
24 & $\begin{array}{l}\text { Integration of OF in } \\
\text { training establishments }\end{array}$ & $\begin{array}{c}\text { Weak, almost } \\
\text { fully segregated }\end{array}$ & $\begin{array}{c}\text { Largely } \\
\text { integrated }\end{array}$ & Nd & $\begin{array}{c}\text { Largely } \\
\text { integrated }\end{array}$ & Largely integrated \\
25 & $\begin{array}{l}\text { Range of research } \\
\text { program }\end{array}$ & $\begin{array}{c}\text { Production } \\
\text { only }\end{array}$ & $\begin{array}{c}\text { Production } \\
\text { only }\end{array}$ & $\begin{array}{c}\text { Almost full } \\
\text { range* }\end{array}$ & Almost full & Full range* for \\
Integration of OF in & Almost none crop & crop and livestock \\
advisory services & Largely & Little & Largely & Largely integrated \\
\hline
\end{tabular}

23) CEEC: Tyburski 2003, Ministry of agriculture websites, SE: Swedish Ministry for Rural Affairs 2012.

24) EE: Milkk 2005, PL: Moschitz et al. 2004, Brent 1999, LV: Zarina 2009, SE: Källander 2000/2010.

25) All: Slabe 2004. *Full range: research programme covers topics of production, food quality, and market development.

26) EE: Milkk 2005, personal communication Eve Ader, Estonian Plant Production Inspectorate, PL: Moschitz et al. 2004,

Brent 1999, LV: Zarina 2009, Drozdovska 2005 LT: Tatulos programa 2005, SE: Källander 2000/2010. 
Table 8 Indicator 27-30: Maturity of the organic market based on physical structures



27) EE: Vetemaa \& Milkk 2012, LV: Latvian Ministry of Agriculture 2006b, Zarina 2009, LT: Lithuanian Ministry of Agriculture 2006, PL: Polish Ministry of agriculture and rural development 2006a, SE: KRAV 2006. *In 2005.

28) EE: Moschitz et al. 2004, Milkk 2005, LV: Gulbe \& Hazners 2005, Terra Nord 2005, LT: Rutkoviene \& Abraityte 2006, PL: Moschitz et al. 2004, SE: FAS 2004.

29) EE: Pehme et al. 2007, LV: Gulbe \& Hazners 2005, Terra Nord 2005, LT: Kaspersen et al. 2004, Rutkoviene \& Abraityte 2006, PL: Bakula \& Smoluk 2005, Kilcher et al. 2011, SE: Dabbert et al. 2004, FAS 2004, Kilcher et al. 2011.

30) EE, LV: based on numbers from countries with similar market characteristic from Dabbert et al. 2004 and Ritcher et al. 2006. LT: Terra Nord 2005. PL: Kilcher et al. 2011. SE: KRAV 2012.

Lithuania and Poland more frequently buy organic products compared to people in Sweden (indicator 33) (Table 8).

At first sight, indicator 30 (market share of organic products) does not correspond with indicator 32 (acceptable price premium for organic products). Half the population is willing to pay a substantial price premium but very few choose to do so. However, the price difference between conventional and organic products that consumers face might be higher than what is stated in indicator 32. This is not examined in the present study. Sweden shows the highest acceptable price premium which corresponds with Sweden having the highest market share of organic products. The questionnaire identified consumer demand for organic products in CEEC as the second most important factor that hinders organic farming (see Table 2). In Sweden and Poland, the reliability of the certification body is good (indicator 34), while it is poor in Estonia and Latvia, and medium in Lithuania (Table 9).

\section{Discussion}

\section{Present and lacking institutions}

According to the results the most important institutions are private and governmental standards for organic production and certification, strategic and financial support measures from the government, and market demand and supply. Missing institutions are identified using the six-step process for the institutional development of the organic sector proposed by Michelsen et al. (2001). The degree of completion, used to identify missing institutions, has been measured by using the indicators describing the characteristics of the steps (see Tables 1, 3, 4, 5, 6, 7, 8, 9). Sweden has been used as a baseline country and the indicators should resemble those of Sweden for a step to be considered completed. A country performing worse than Sweden in one-third of the indicators scores half-way. A country performing worse than Sweden in two-thirds of the 
Table 9 Indicator 31-34: Maturity of the organic market based on consumer behaviour

\begin{tabular}{|c|c|c|c|c|c|c|}
\hline & & Estonia & Latvia & Lithuania & Poland & Sweden \\
\hline \multirow[t]{2}{*}{31} & Proportion of consumer that can correctly & Medium & Medium & Medium & Low $30 \%$ & High \\
\hline & & $65 \%$ & $70 \%$ & $70 \%$ & & $93 \% * *$ \\
\hline 32 & $\begin{array}{l}\text { Acceptable price premium (in\% higher) by } \\
\text { half the population }\end{array}$ & $10 \%$ & Very low* & $25 \%$ & $10-20 \%$ & $30 \%$ \\
\hline 33 & $\begin{array}{l}\% \text { of the population that buy } \mathrm{OP}>\text { once a } \\
\text { week } />\text { once a month } /<\text { once a month }\end{array}$ & nd & nd & $35 / 32 / 33$ & $17 / 48 / 33$ & $6 / 48 / 45$ \\
\hline 34 & $\begin{array}{l}\text { Perception of the quality of certification } \\
\text { and control system* }\end{array}$ & Poor & Poor & Medium & Good & Good \\
\hline
\end{tabular}

31) EE: Pehme et al. 2007, LV: Gulbe \& Hazners 2005, LT: Rutkoviene \& Abraityte 2006, PL: Kucińska et al. 2006, SE: KRAV 2006. ${ }^{* *} 93 \%$ recognise KRAV logo and associate it with organic farming.

32) EE: Milkk 2005, LV: Gulbe \& Hazners 2005, LT: Rutkoviene \& Abraityte 2006, PL: Kucińska et al. 2006, Bakula \& Smoluk 2005, SE: Dabbert et al. 2004. * $4 \%$ are ready to pay $30 \%$ price premium, $21 \%$ are ready to pay a price premium (Gulbe $\&$ Hazners 2005).

33) LT: Rutkoviene \& Abraityte 2006, PL: Bakula \& Smoluk 2005, SE: Terra Nord 2005.

34) CEEC: Prazan et al. 2004 * This study does not depict the point of view of the consumer directly, but the point of view from ministry of agriculture, organic producers' association, organic farmer advisors, and organic farmers. However, the deficiencies that are perceived by major actors are likely to be transmitted to the general public. SE: Michelsen \& Søgaard 2001.

indicators, or more, scores beginning. This is a rough estimate and it should not be interpreted as the situation in Sweden being perfect from the perspective of organic farming. Michelsen et al. (2001) acknowledge that a step can begin without the previous one being completed. This was also observed in the present study (Table 10).

The data also suggest that step 5 is the most difficult step to complete and might be dependent on the completion of the other steps to be completed. For all CEEC, step 6 is half-way while step 5 is still beginning. Furthermore, even Sweden which has completed all the steps still has a small market (step 5). The result that market development is the main hindering factor for the development of the organic sector, is supported by Terra Nord (2005) and DFAF (2001). The development of the organic market in CEEC reflects the economic situation compared with the wealthier EU15. Furthermore, although infrastructures are not considered the most important factors hindering organic farming, they need to improve to allow its full development according to the questionnaire. For example, the quality of the road network and the availability of water and electricity services would benefit organic as well as conventional production.

Table 10 Degree of completion of the six-step process of the institutional development of the organic sector

\begin{tabular}{|c|c|c|c|c|c|c|}
\hline & $\begin{array}{c}\text { Step 1 } \\
\text { Organic } \\
\text { community }\end{array}$ & $\begin{array}{c}\text { Step 2 } \\
\text { Political } \\
\text { recognition }\end{array}$ & $\begin{array}{c}\text { Step } 3 \\
\text { Financial } \\
\text { support }\end{array}$ & $\begin{array}{c}\text { Step } 4 \\
\text { Type of } \\
\text { relationship }\end{array}$ & $\begin{array}{c}\text { Step } 5 \\
\text { Organic market }\end{array}$ & $\begin{array}{c}\text { Step } 6 \\
\text { Discussion and } \\
\text { coordination arena }\end{array}$ \\
\hline $\mathrm{EE}$ & $\begin{array}{l}\text { Half-way } \\
\text { (eroded) }\end{array}$ & $\begin{array}{l}\text { Beginning } \\
\text { (eroded) }\end{array}$ & Beginning & $\begin{array}{l}\text { Competition } \\
\text { (eroded) }\end{array}$ & Beginning* & Half-way \\
\hline LV & $\begin{array}{c}\text { Half-way } \\
\text { (near completed) }\end{array}$ & Half-way & Beginning & $\begin{array}{l}\text { Cooperation/ } \\
\text { Competition }\end{array}$ & Beginning* & Half-way \\
\hline LT & Completed & Completed & Half-way & $\begin{array}{l}\text { Cooperation/ } \\
\text { Competition* }\end{array}$ & $\begin{array}{l}\text { Beginning/ } \\
\text { Half-way }\end{array}$ & Half-way* \\
\hline $\mathrm{PL}$ & Half-way* & $\begin{array}{c}\text { Half-way } \\
\text { (increasing) }\end{array}$ & Half-way & $\begin{array}{l}\text { Cooperation/ } \\
\text { Competition }\end{array}$ & $\begin{array}{l}\text { Beginning/ } \\
\text { Half-way }\end{array}$ & Half-way \\
\hline SE & Completed & Completed & Completed* & $\begin{array}{c}\text { Cooperation/ } \\
\text { Creative conflict }\end{array}$ & $\begin{array}{c}\text { Completed } \\
\text { (although still small) }\end{array}$ & Completed \\
\hline
\end{tabular}

Italic letters indicates that the step is only beginning, italic bold letters that the step is half way, and normal type letters that the step is completed. The evaluation of the completion of each step is based on the indicators described in the result section. The ${ }^{*}$ symbol means that data for one indicator is missing. 
The political recognition and willingness to financially promote organic farming is reflected in the degree of completion of step 2 to 4 . Table 10 suggests that the government of Lithuania has a high political willingness, followed by Poland and Latvia. Latvia invests proportionally more in organic farming and has higher strategic support, while Poland focuses more on partnership and discussion. In Estonia the political willingness is lower. When considering the amount of money invested in organic farming, it should be kept in mind that the CEEC have a lower GDP per capita than EU15 or Sweden, which limits what they can invest. This is also relevant in relation to the CAP support, since the support devoted to organic farming (pillar II of CAP) requires co-finance from the member states.

Figure 2 illustrates the number of certified organic farms in the studied countries. Over time the number increases in all countries. The introduction of area payment (indicator 10) seems to have had a positive effect in Poland (area payments introduced in 1999) and to some extent in Estonia and Latvia (area payments introduced in 2000 and 2001 respectively) whereas for Lithuania there is a ten year lag (area payments introduced in 1993). For both Poland and the Baltic states the accession to the EU in 2004 seems to be have been more important and the number of certified farms accelerated in the period 2003-2005. The best explanation for the rapid increase in reported Swedish organic farms, followed by a decrease, is that different sources have been used. In practice, the number of certified organic farms have increased slowly, and rather steadily, over time.

Data over organically cultivated area follow a similar pattern with two differences. Whereas the number of organically certified farms increased fast in Poland, the amount of organically cultivated land increased at a lower rate indicating that smaller farms to a larger degree converted to organic standards (EkoConnect 2006). In contrast, Estonia, showing moderate growth rate of organically certified farms experienced a faster than average growth of organically cultivated land. In Sweden 12.6\% of the agricultural land was organically cultivated in 2011, an increase from 10.7\% in 2010. Another 3.5\% of agricultural land was under conversion (Statistics Sweden 2012) which is not enough to reach the politically set target of $20 \%$ organically cultivated land by 2013 . This can be compared with a rather modest market share of organic production (indicator 30) of $4.1 \%$. Why the two figures differ is not investigated here.

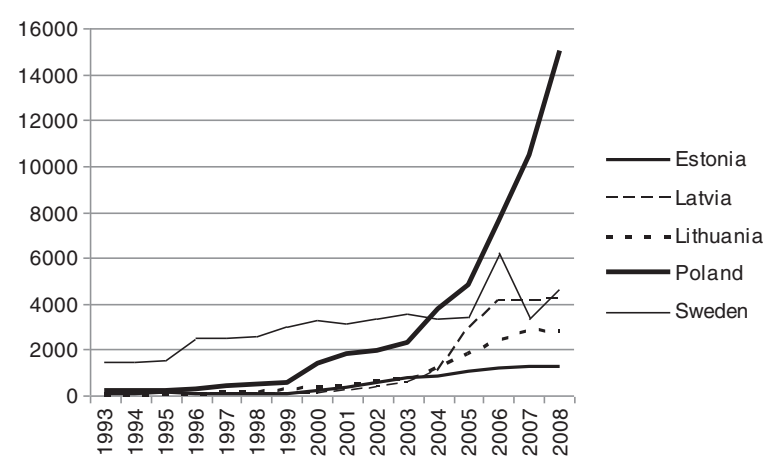

Figure 2 Number of certified organic farms over time in the five case-study countries. This might differ from the number of farms that are cultivated organically. Compiled from different sources. CEEC: EkoConnect 2006; Eurostat 2012b. Sweden: Källander 2000/2010; Statistics Sweden 2002, 2005; Eurostat 2012b. 
Ways to promote institutional development through the six steps

Step 1 is the only step that pertains to the establishment of institutions within the civil society domain. The step begins by the self-organisation of a group of organic farmers into a producers' association (Michelsen et al. 2001). Step 1 can be promoted by governments with the money of the European Agricultural Fund for Rural Development (EAFRD) which has a provision for the establishment and operation of producers' associations (EEC 1698-2005 ${ }^{\mathrm{e}}$ ). However, Moschitz et al. (2004) argue that the identity of the community should develop by itself, otherwise its acceptance by most actors is difficult. In a similar vein Milestad (2003), in a study of Austrian farmers, argues that subsidies on the one hand makes a transition to organic farming possible but on the other hand influence farmers in a direction they might not have chosen if it was not for the subsidy. They experience a loss of independence.

Steps 2 and 3 are where governments have the most power to act. To increase the support stemming from political recognition, Dabbert et al. (2004) suggest that governments should acknowledge the possibility of organic farming to fulfill multiple policy objectives. This can be fostered by research, by discussion, and by partnership, which all increase the understanding of organic farming.

Step 5 is influenced by the actors in all three societal domains. The example of Sweden has shown that producers' associations can have significant impact, especially in the beginning, because they are the first to lobby large retailers and to provide marketing initiatives. In addition, market actors, such as large retailers, have proven that they can have a clear leadership role in promoting organic farming in Sweden (Källander 2000/2010; FAS 2004). Finally, governments can favour the establishment of processors by providing guaranteed loans or lower income tax to this type of enterprise (Terra Nord 2005). Governments can also stimulate the market by, for example, increasing public procurement of organic food (Larsson 2012; Larsson et al. 2012) or even making the use of organic products in public catering mandatory (Edman 2004).

The development of steps 4 and 6 are closely related because the development of cooperative relationships often involves discussion and partnerships, which may in turn involve the development of official discussion and coordination arenas to facilitate this. A stakeholders' survey at the European level identified the establishment of a national organic network or a national advisory committee grouping farmers, market actors and the state as a good way to facilitate coordination (Zerger et al. 2005). The government is not the only actor who can promote this step. Boström (2006) proposes that the discussion arena can be the administrative board and committees of a certification body. Effectively, certification and labelling play a central role for all the actors of the organic sector, creating incentives for discussion and coordination (Boström 2006).

\section{Conclusion}

Organic farming is proposed as a way to improve the environmental situation of the Baltic Sea, including reduced eutrophication. This paper furthers the understanding of the institutional factors that hinder the development of organic farming in the CEEC. The results support previous work of Michelsen et al. (2001) that proposes that the development of organic farming proceeds along six steps. According to the results, the market (step 5) is the least developed step. A well functioning market would further promote the development of organic farming, but this step is identified as being 
difficult to complete. The results also suggest a correlation between higher political willingness to promote the organic sector and more advanced development of the sector.

In all studied CEEC, the window of opportunity offered by the entry to the EU has been used to some extent when establishing a regulatory framework and financial help. However, there is still a long way to go before the organic sector in these countries is fully developed. Lithuania is the CEEC with the most steps of institutional development completed. Latvia and Poland are half-way through most of the steps. Estonia is the country with the least completed steps.

The results also provide support for decision makers that want to promote organic farming effectively. We chose not to give country specific recommendations but there are some general recommendations to be drawn from the results. The first recommendation, drawn from the questionnaire, for all CEEC is to ensure support, including financial support, to organic farming that develops the independence and selforganisation of the organic sector. The second recommendation, following the poor performance of step 5 in combination with its importance, is that support should be directed towards a market-oriented approach. The third recommendation is to foster discussion, collaboration and coordination between all the actors. This is central to many steps in the development of organic farming and it can further the understanding of each actor and increase the level of support to organic farming.

\section{Endnotes}

${ }^{a}$ The Helsinki Commission, or HELCOM, works to protect the marine environment of the Baltic Sea from all sources of pollution through intergovernmental co-operation between Denmark, Estonia, the European Community, Finland, Germany, Latvia, Lithuania, Poland, Russia and Sweden. See www.helcom.fi.

${ }^{b}$ From this point, the term CEEC refers only to Estonia, Latvia, Lithuania and Poland.

${ }^{c}$ On January 12009 the new EU regulation (EC) No 834/2007 came into effect in all EU member states, replacing the previous regulation EEC 2092-91: Council Regulation (EEC) No 2092/91.

${ }^{d}$ EEC 2078-92: Council Regulation (EEC) No 2078/92. Official journal of the European Union. L 215, 30/07/1992, p 85-90.

${ }^{e}$ EEC 1698/2005: Council Regulation (EEC) No 1698/2005. Official journal of the European Union. L 277, 21/10/2005, p 1-40.

Competing interests

The authors declare no conflict of interests.

Authors' contributions

ML and LM both took part in drafting the text, analysing and interpreting data. LM collected the bulk of the data and $\mathrm{ML}, \mathrm{TH}$ and JS finalised the text.

Acknowledgements

We are most thankful to two anonymous reviewers for valuable comments and the research programme Baltic Ecological Recycle Agriculture and Society (www.beras.eu) for supporting this work.

${ }^{1}$ Stockholm Resilience Centre, Stockholm University, Kräftriket 2B, Stockholm SE-106 91, Sweden. ${ }^{2}$ Mälardalens högskola, Box 883, Västerås 721 23, Sweden. ${ }^{3}$ Swedish Society for Nature Conservation, Box 4625, Stockholm 11691 , Sweden. 
Received: 10 July 2012 Accepted: 5 April 2013

Published: 21 May 2013

\section{References}

Bakula WL, Smoluk J (2005) The perception of Polish organic food consumers. Paper presented at the 8th Wissenschaftstagung Ökologischer Landbau - Ende der Nische. Hohenheim University, Kassel, http://orgprints.org/3943/01/3943.pdf. Accessed June 262012

Baylis J, Smith S (2001) The globalization of world politics. An introduction to international relations. Oxford University Press, New York

Boström M (2006) Regulatory credibility and authority through inclusiveness: standardization organization in cases of eco-labelling. Organization 13(3):345-367

Boström M, Klintman M (2003) Framing, debating, and standardising "natural food" in two different political contexts: Sweden and the U.S. Score Rapportserie. Stockholm University, Stockholm

Brent JK (1999) Extension, research and farm competitiveness in Central and Eastern Europe. Paper presented at the 2nd EU Accession Workshop on the Rural Sector, Structural change in the farming sectors of Central and Eastern Europe: lessons and implications for EU accession", June 27-29 1999. Warsaw, http://www.fao.org/sd/exdirect/EXan0037.htm. Accessed June 262012

Buciene A, Eidukeviciene M (2005) How viable is the local organic food market in Klaipeda town and district from the consumer's point of view? P 9-20. In: Kakriainen S, von Essen H (eds) Obstacles and solutions in use of local and organic food. Baltic Ecological Recycling Agriculture and Society (BERAS) 4. Ekologiskt lanbruk 44. Centre for sustainable agriculture, Swedish University of agricultural sciences, Uppsala

Dabbert S, Häring AM, Zanoli R (2004) Organic farming: policies and prospects. Zed books, London and New York

DFAF (Danish ministry of food, agriculture and fisheries) (2001) Organic food and farming: toward partnership and action in Europe. Conference proceedings, Copenhagen

Diaz RJ, Rosenberg R (2008) Spreading dead zones and consequences for marine ecosystems. Science 321:926-929

Drozdovska L (2005) Organic agriculture in Latvia, Environmental friendly food production system: requirements for plant breeding and seed production. Conference proceedings, Talsi, pp 42-45

Edman S (2004) Hållbara laster, Konsumtion för en ljusare framtid. Government Commission Report/SOU 2004:119. Swedish Ministry of Agriculture, Stockholm

EkoConnect (2006) Development of the total organic area in countries of Central and Eastern Europe (in ha). http://www.ekoconnect.org/pdf/06-02-27_development_cee.pdf. Accessed June 152012

Estonian Ministry of Agriculture (2002) Estonia agriculture, rural economy and food industry. Tallinn, http://www.agri.ee

Estonian Ministry of Agriculture (2006) Estonia Rural Development Plan: 2007-2013. Tallinn

EU (2004) European Action Plan for Organic Food and Farming, Commission Staff Working Document. Annex to COM (2004)415 final, SEC(2004) 739. Brussels

Eurostat (2012a) Newsrelease 97/2012 - 20 June 2012: GDP per capita in the Member States ranged from 45\% to 274\% of the EU27 average in 2011. http://epp.eurostat.ec.europa.eu/cache/ITY_PUBLIC/2-20062012-AP/EN/2-20062012-AP-EN.PDF. Accessed June 26, 2012

Eurostat (2012b) Number of certified organic operators [food_act2]. http://appsso.eurostat.ec.europa.eu/nui/show.do? dataset=food_act2\&lang=en. Accessed June 26, 2012

FAO (2002) Central and Eastern Europe and the commonwealth of independent states, The state of food and agriculture. Rome

FAS (USAD Foreign Agricultural Service) (2004) Organic Products: Swedish Market for Organic Products. GAIN Report: SW4012. http://www.fas.usda.gov/gainfiles/200409/146107434.pdf. Accessed June 27, 2012

Fischler F (2003) Future perspectives for organic farming in an enlarged EU. Speech given at the conference Perspectives of Organic Agriculture in an Enlarged EU, November 21s 2003, Plovdiv., SPEECH/03/562 http://europa.eu/rapid/pressReleasesAction.do?reference=SPEECH/03/562\&format=PDF\&aged=1\&language=EN\&guilanguage=en Accessed June 26, 2012

Granstedt A, Thomsson O, Schneider T (2005) Environmental impacts of Baltic ecological food systems: final report from BERAS work package 2. Ecological Recycling Agriculture and Society (BERAS) 5. Ekologiskt lantbruk 46. Centre for Sustainable Agriculture, Swedish University of Agricultural Sciences, Uppsala

Gulbe I, Hāzners J (2005) Development and implementation of collective trademarks and food labels in Latvia: label for organic food "ECOPRODUCT". Paper presented at NJF seminar 381, The Northern European food industry challenges and transitions from an economic perspective, seminar of the Nordic association of agricultural scientists. Helsinki

Hajduk E, Staniszewska M (2005) Development of local organic markets and other environmentally oriented activities in Poland: Cases of Kluzborg and Bochnia and Zbiczno. In: Kakriainen S, von Essen H (eds) Obstacles and solutions in use of local and organic food. Baltic Ecological Recycling Agriculture and Society (BERAS) 4. Ekologiskt lantbruk 44. Centre for Sustainable Agriculture, Swedish University of Agricultural Sciences, Uppsala, pp 20-35

Hannerz F, Destouni G (2006) Spatial characterization of the Baltic Sea Drainage Basin and its unmonitored catchments. Ambio 35(5):214-219

HELCOM (2002) Sixth meeting of working group on agriculture, October 21-22 2002. Helsinki Commission, Kiel HELCOM (2004) 30 years of protecting the Baltic Sea: HELCOM 1974-2004. Helsinki commission, Helsinki HELCOM (2011) Baltic Sea Environment Proceedings No. 128. Fifth Baltic Sea Pollution Load Compilation (PLC-5), Helsinki Hrabalova A, Handlova J, Koutna K, Zdrahal I (2005) Further development of organic farming policy in Europe with particular emphasis on EU enlargement. Report on the development of organic farming in CEE accession states with national report cards (final report). QLK5-2002-00917. Research Institute of Agricultural Economics, Brno

IUCN (2004) Gaps and Limitations of the Rural Development: Plans of the CEE New Member States. Foundation IUCN Poland (IUCN Programme Office for Central Europe). http://data.iucn.org/dbtw-wpd/edocs/EEP-041.pdf. Accessed June 26, 2012 
Jansen B, Simon S (2005) Country Report: Organic agriculture in Lithuania. EkoConnect information letter organic agriculture of Central and Eastern Europe. http://www.ekoconnect.org/pdf/Infobrief_5/Infobrief-5-Englisch.pdf. Accessed June 26, 2012

Källander I (2000/2010) Organic Agriculture in Sweden. FiBL Country Reports (edited 2010). http://www.organic-world. net/fileadmin/documents/country_information/sweden/kaellander-2000-sweden-2000.pdf. Accessed June 27, 2012

Kalm U, Laansalu A (2002) Estonia agriculture, rural economy and food industry status report. Ministry of agriculture, Republic of Estonia, Tallin

Kaspersen BS, Mikkelsen KD, Jacobsen C (2004) Organic agriculture in the light of EU enlargement - A window of opportunity. Thesis (\#2193), Institut for Miljø, Teknologi og Samfund, Roskilde University. http://dspace.ruc.dk/bitstream/1800/217/1/Organic_Agriculture_in.pdf. Accessed June 27, 2012

Kilcher L, Willer H, Huber B, Frieden C, Schmutz R, Schmid O (2011) The Organic Market in Europe, 3rd edn. FiBL and Sippo, Frick and Zürich

KRAV (2006) Annual Report 2005. KRAV Incorporated Association, Uppsala

KRAV (2012) Marketing Report. www.krav.se. Accessed June 152012

Kucińska K, Pelc I, Artyszak A (2006) Development of Organic Agriculture in Poland. Paper presented at Joint Organic Congress, Organic Farming and European Rural Development, Odense. May 30-31, 2006

Lampkin N, Foster C, Padel S, Midmore P (1999) The policy and regulatory environment for organic farming in Europe: synthesis of results. Organic farming in Europe, Economics and policy, vol 1. Hohenheim University, Stuttgart

Larsson M (2012) Environmental entrepreneurship in organic agriculture in Järna, Sweden. J Sustain Agric 36:153-179

Larsson M, Granstedt A (2010) Sustainable governance of the agriculture and the Baltic Sea - Agricultural reforms, food production and curbed eutrophication. Ecol Econ 69:1943-1951

Larsson M, Granstedt A, Thomsson O (2012) Sustainable Food System - Targeting Production Methods, Distribution or Food Basket Content? In: Reed M (ed) Organic Food and Agriculture - New Trends and Developments in the Socia Sciences. InTech. http://www.intechopen.com/books/organic-food-and-agriculture-new-trends-and-developmentsin-the-social-sciences/sustainable-food-system-targeting-production-methods-distribution-or-food-basket-content-. Accessed June 27, 2012

Latvian Council of Science (2006) Projects of fundamental and applied research for the year 2006: agricultural sciences. Latvian Council of Science, Riga

Latvian Ministry of Agriculture (2006a) Agriculture and Rural Area of Latvia. Riga, pp 115-117, http://www.zm.gov.lv Latvian Ministry of Agriculture (2006b) Latvian Rural Development National Strategy Plan: 2007-2013. Riga

Lerman Z (2001) Agriculture in transition economies: from common heritage to divergence. Agric Econ 26:95-114

Lithuanian Ministry of Agriculture (2005) Annual report: agriculture in Lithuania 2005. http://www.zum.lt

Lithuanian Ministry of Agriculture (2006) Rural Development Programme 2007-2013. http://www.zum.lt

Metera D (2005) Organic Farming in Poland: Update July 2005. http://www.organic-europe.net/fileadmin/documents/ country_information/ARCHIVE/poland-2005-organic-europe.pdf. Accessed June 27, 2012

Michelsen J, Søgaard V (2001) Policy instruments promoting conversion to organic farming and their in Europe 1985-1997. Department of Political Sciences and Public Management, University of Southern Denmark, Odense

Michelsen J, Lynggaard K, Padel S, Foster C (2001) Organic farming development and agricultural institutions in Europe: a study of six countries. Organic farming in Europe: economics and policy, vol 9. University of Hohenheim, Stuttgart

Milestad R (2003) Building farm resilience. Prospects and challenges for organic farming, Dissertation. The Swedish University of Agricultural Sciences, Uppsala

Milkk M (2005) Organic agriculture in Estonia. In: Belicka I, Viklante M, Arbidans M (eds) Proceedings of Environmental friendly food production system: requirements for plant breeding and seed production, Talsi. May 31-June 3

Moschitz H, Stolze M, Michelsen J (2004) Further development of organic farming policy in Europe with particular emphasis on EU enlargement, Report on the development of political institutions involved in policy elaboration in organic farming for selected European states (deliverable 7). Available via http:/orgprints.org/4799/1/EUCEEOFP_D7_final_report.pdf. Accessed 16 April, 2013

North DC (1990) Institutions, Institutional Change and Economic Performance. Cambridge University Press, Cambridge

Pehme S, Luik A, Liivaauk P (2007) Estonian consumers' attitudes to organic food, Paper presented at the 3rd QLIF Congress, Improving Sustainability in Organic and Low Input Food Production Systems. University of Hohenheim, Germany

Petersen J-E, Hoogeveen Y (eds) (2004) Agriculture and the environment in the EU accession countries. Environmental issue report No 37. European Environmental Agency, Copenhagen

Polish Central Statistical Office (2007) Concise Statistical Yearbook of Poland 2006. Warsaw

Polish Ministry of Agriculture and Rural Development (2006a) Annual report: Agriculture and food economy in Poland. Warsaw, http://www.minrol.gov.pl

Polish Ministry of Agriculture and Rural Development (2006b) National Strategic Plan for 2007-2013 Rural Development. Warsaw

Porter E (2006) Agricultural Situation Organic farming in Poland - update 2006.Global Agriculture Information Network of the USDA Foreign Agricultural Service. GAIN Report. PL603. http://www.fas.usda.gov/gainfiles/200606/146197948.pdf. Accessed June 30, 2012

Prazan J, Koutna K, Skorpikova A (2004) Report on the development of organic farming and the policy environment in Central and Eastern European accession states, 1997-2002 (deliverable 6). EU-CEEOFP project report

Richter T, Padel S, Lowman S, Jansen B (2006) The European Market for Organic Food 2004/2005. In: Willer H, Yussefi M (eds) The world of organic agriculture: statistics and emerging trends 2006. International Federation of Organic Agriculture Movements (IFOAM), Bonn Germany \& Research Institute of Organic Agriculture (FiBL), Frick, Switzerland

Rush C (2006) Lithuania organic products - organic farming in Lithuania 2006. Global Agriculture Information Network of the USDA Foreign Agricultural Service. GAIN Report. LH6002. http://www.fas.usda.gov/gainfiles/200606/146198110.pdf. Accessed June 30, 2012

Rutkoviene V, Abraityte G (2006) Organic markets and consumers in Lithuania. Paper presented at the Joint Organic Congress, Organic Farming and European Rural Development, Odense, Denmark. http:/orgprints.org/8552/01/naujas_danija.doc. Accessed June 30, 2012 
Sandström A (2008) Policy Networks: The relation between structure and performance, Dissertation. Luleå University of Technology, Luleå

Schultz M, Folke C, Olsson P (2007) Enhancing ecosystem management through social-ecological inventories: lessons from Kristianstads Vattenrike, Sweden. Environ Conserv 34(2):140-152

Schusseleder G (2009) Konsten att undvika GMO. Ordfront Magasin, 3:2009. http://www.ordfront.se/Ordfrontmagasin/ Artiklar\%202009/Goran\%20Schusseleder\%20om\%20GMO\%203_09.aspx. Accessed June 26, 2012

Slabe A (2004) How to improve trans-national cooperation? Consolidated report on 2nd seminar on organic food and farming research in Europe. European Commission, Research Directorate General, Brussels

Statistics Estonia (2007) Research and development expenditures in non-profit institutional sectors, Tallinn

Statistics Sweden (2002) Swedish agricultural year book. Chapter 11: Ekologisk produktion/ Organic production. http://www.scb.se/statistik/JO/JO1901/2003M00/JO01S\%C3\%850201_19.pdf. Accessed June 30, 2012

Statistics Sweden (2005) Swedish agricultural year book. Chapter 11: Ekologisk production/Organic production. http://www.scb.se/statistik__publikationer/J01901_2005A01_BR_JO01SA0501.pdf. Accessed June 30, 2012

Statistics Sweden (2012) Swedish agricultural year book. Chapter 11: Ekologisk produktion/Organic production. http://www.scb.se/statistik/_publikationer/JO1901_2012A01_BR_17_JO01BR1201.pdf. Accessed June 302012

Stolze M, Piorr A, Häring A, Dabbert S (2000) The environmental impacts of organic farming in Europe, Organic farming in Europe: economics and policy, vol 6. Hohenheim Univeristy, Stuttgart

Swedish Board of Agriculture (2012) http://www.jordbruksverket.se/jordbruksverketslattlastasidor/stodtilllandsbygden/ miljoersattningar/certifieradekologiskproduktionellerkretsloppsinriktadproduktion.4.795c224d1274198ffc280003186. html. Accessed June 27, 2012

Swedish Ministry for Rural Affairs (former Ministry of Agriculture) (2012) http://www.sweden.gov.se/sb/d/2064, Accessed June 30, 2012

Swedish Ministry of Agriculture (2008) Swedish rural development programme 2007-2013. http://www.regeringen.se/sb/d/ 8723/a/82731. Accessed June 30, 2012

Tatulos programa (2005) Web portal about organic agriculture in Lithuania. www.organic.lt. Accessed March 17, 2007

Terra Nord (2005) Development of the Nordic-Baltic Market for Organic Food. Nordic Council of Ministers, Copenhagen www.norden.org/pub/miljo/jordogskov/sk/TN2005548.pdf. Accessed June 30, 2012

Tuson J, Lampkin NH (2006) Further development of organic farming policy in Europe with particular emphasis on EU enlargement, Report detailing national and regional OF policy measures in EU states and Switzerland (deliverable 2). EU-CEE-OFP project report

Tyburski J (2003) Organic farming in Poland: Past, present and future perspectives, Organic agriculture: sustainability, market and policies. CABI publishing, Wallingford

Tyburski J, Zakowska-Biemans S (2003) Further development of organic farming policy in Europe with particular emphasis on EU enlargement, Report on Harmonisation of Regulations and Standards for Organic Agriculture in the Central and Eastern Europe Accession Countries and the European Union (deliverable 1). QLK5-2002-00917

Vetemaa A, Milkk A (2012) Organic Farming in Estonia. http://www.organic-europe.net/estonia.html?\&L=0\#c2927. Accessed June 27, 2012

Yin R (2003) Case study research: Design and methods, 3rd edn. Sage Publications, Thousand Oaks

Zarina L (2009) Organic Farming in Europe: country report for Latvia. http://www.organic-europe.net/latvia.html?\&L=0 Accessed June 30, 2012

Zerger C, Vairo D, Häring AM, Zanoli R, Dabbert S (2005) Implementation of policy recommendations on organic farming: A cross-country synthesis of national policy workshops in 11 European countries. EU-CEE-OFP project report available via https://www.uni-hohenheim.de/i410a/EUCEEOFP/WP7_WS3_Synthesis_report_final.pdf

Zobena A (1998) Organic farming in the Baltic countries social aspects of development. In: Vlavianos-Arvanitis A, Morovic J (eds) Biopolitics, vol VI, The Bio-Environment. The Biopolitics International Organisation, Athens, Available at http://www.biopolitics.gr/BIOPOLITICS/HTML/PUBS/NOL6/HTML/fpage.htm

doi:10.1186/2193-7532-1-5

Cite this article as: Larsson et al:: Institutional barriers to organic farming in Central and Eastern European countries of the Baltic Sea region. Agricultural and Food Economics 2013 1:5.

\section{Submit your manuscript to a SpringerOpen ${ }^{\circ}$} journal and benefit from:

- Convenient online submission

- Rigorous peer review

- Immediate publication on acceptance

- Open access: articles freely available online

- High visibility within the field

- Retaining the copyright to your article

Submit your next manuscript at $\boldsymbol{\sim}$ springeropen.com 